\title{
The Impact of Knowledge Management Orientation on New Product Commercialization: The Mediating Role of Market Orientation
}

\author{
${\text { Mehdi Rasouli Ghahroudi }{ }^{*} \text {, Yasuo Hoshino², Fereshteh Ahmadpoury }}^{3}$ \\ ${ }^{1}$ International Business Management, Institute for Management and Planning Studies (IMPS), Tehran, Iran \\ ${ }^{2}$ Management and Finance, University of Tsukuba, Tsukuba, Japan \\ ${ }^{3}$ International Business, Institute for Management and Planning Studies (IMPS), Tehran, Iran \\ Email:^m.rasouli@imps.ac.ir, hoshino@sk.tsukuba.ac.jp,fereshtehahmadpoury@yahoo.com
}

How to cite this paper: Ghahroudi, M.R., Hoshino, Y. and Ahmadpoury, F. (2019) The Impact of Knowledge Management Orientation on New Product Commercialization: The Mediating Role of Market Orientation. American Journal of Industrial and Business Management, 9, 1949-1968.

https://doi.org/10.4236/ajibm.2019.910127

Received: September 3, 2019

Accepted: October 28, 2019

Published: October 31, 2019

Copyright $\odot 2019$ by author(s) and Scientific Research Publishing Inc. This work is licensed under the Creative Commons Attribution International License (CC BY 4.0).

http://creativecommons.org/licenses/by/4.0/

\begin{abstract}
The knowledge management orientations that firms adopt as a business input may lead at least partially to the superior performance of the new products they introduce to the market. Our empirical research investigates the knowledge management orientation effect on new product commercialization performance, using data collected from 700 Iranian manufacturing firms in six industries including plastic, steel manufacturing, construction, machinery, stone, mine, and Nano industries. However, our final sample due to missing data is 252 firms. Further, we study the mediating role of proactive and responsive market orientation. Our findings indicate that knowledge management orientation is positively associated with three aspects of new product commercialization, namely product advantage, new product development, and the number of new products introduced to the market. However, there was no significant mediating role in market orientation. Finally, our results show that market orientation and knowledge management orientation affect commercialization performance and therefore could improve new product commercialization.
\end{abstract}

\section{Keywords}

Knowledge Management Orientation, Proactive, Responsive, Market Orientation, New Product Commercialization

\section{Introduction}

Continuous environmental changes such as changing customer tastes and market needs threaten the survival of organizations in different ways. Under such 
conditions, market success and sustainable competitive advantage depend on appropriate market predictions and new product development that meets customer needs. Thus, the successful introduction of new products to the market (i.e., commercialization) is crucial for the corporations.

Iran ranked as the 89th most competitive nation in the world in the year 2018 based on the Global Competitiveness Report published by the World Economic Forum. As of 2014, 81,000 small industrial enterprises employed more than 1 million workers in Iran. Small industries constitute 92 percent of Iranian industries, 45 percent of the country's industrial employment, and 17 percent of the country's production. However, because of its weakness or absence, the support industry makes little contribution to the innovation/technology development activities. In 2016, Iran had nearly 3000 knowledge-based firms accounting for 70,000 jobs and $\$ 6.6$ billion in revenue (UNCTAD, 2016) [1].

Technology described as the engine of progress, wealth generation, and economic growth (Allen, 2012; Dorff \& Worthington, 1987) [2] [3]. Although technology alone does not generate wealth, its emergence, in the form of products and services, generates wealth through the commercialization of technological inventions and innovations (Frishammar et al., 2012; Heslop et al., 2001) [4] [5].

Dynamic capability theory suggests that: 1) firms vary in their ability to control, access, and organize productive resources, suggesting that the capacity of a firm to purposefully create, extend, and modify its resource base determines firm performance (Helfat et al., 2007) [6]; 2) differences in resources and firm abilities at least partially explain performance variations among close competitors (Eisenhardt \& Martin, 2000) [7]; and 3) firms need to have capabilities that not only allow them to exploit internal resources but also permit them to access, configure, and leverage external network resources embedded in business partners (e.g., Teece, 2007) [8].

The market-oriented approach refers to the ability of a firm to compete by predicting market requirements and creating long-term relations with customers and suppliers (Schindehutte et al., 2008) [9]. Acquiring knowledge on customers and competitors and sharing these data among the functional areas in a firm are key dimensions of market orientation (Kohli \& Jaworski, 1990; Narver \& Slater, 1990) [10] [11]. The ability to integrate knowledge and use it to create new knowledge in organizations is an important factor in commercialization (Frishammar et al., 2012) [4].

The commercialization of innovations requires suitable and effective support that can improve performance. Organizational support or perceived organizational support explains how an organization encourages its human resources to meet its goals (Colakoglu et al., 2010) [12]. From this point of view, organizational support that influences commercialization performance, includes IT technology (Cho \& Lee, 2013; Durmuşoğlu \& Barczak, 2011; Protogerou et al., 2011) [13] [14] [15], top management support (Harmancioglu, 2010; Martín-Rojas, 2013) [16] [17], and the organization's capabilities such as marketing (Kim et al., 2011; 
Wilden et al., 2013) [18] [19], R\&D (Kim et al., 2011) [18], NPD (Lew \& Sinkovics, 2013) [20], and creativity (Kock et al., 2011) [21].

The knowledge factors (e.g., market knowledge, knowledge integration and exploitation, explicit and implicit knowledge) are also effective for accelerating the commercialization (Heng, 2012) [22]. Knowledge management can enable companies to improve their commercialization performance (Chiang \& Shih, 2011; Frishammar et al., 2012) [4] [23]. Further, the literature suggests that knowledge is critical to the performance of NPD (Chiang \& Shih, 2011) [23] and leads to improvements in product innovation performance (Kostopoulos et al., 2011) [24]. However, few studies have investigated the effect of knowledge orientation on commercialization.

Moreover, although marketing and strategic management researchers have shown that the relationship between market orientation and knowledge management affects corporate performance, the effectiveness of such variables on commercialization in Iranian corporations has been neglected. The current research examines the effects of these variables on new product commercialization.

\section{Literature Review}

\subsection{New Product Commercialization}

The commercialization of innovations requires proper and effective support to be able to improve performance. The organizational support or perceived organizational support points to how a corporation encourages its workforces to meet the goals of the organization (Colakoglu et al., 2010) [12]. Furthermore, the organizational support influencing commercialization performance, are technology (Cho \& Lee, 2013) [13]; the patent system (Datta et al., 2011) [25]; Organizational capabilities such as marketing and production (Kim et al., 2011) [18]; R \& D, and learning or education (Kim et al., 2011; Park \& Ryu, 2015) [18] [26]; rewards (Lam, 2011) [27]; and organizational creativity (Kock et al., 2011; Wu, 2010) [21] [28].

Moreover, the knowledge factor is effective in accelerating commercialization (Heng et al., 2012) [22]. While many researchers studied commercialization of knowledge and related literature, however, few studies have examined the effect of knowledge on the commercialization of technology and products.

The strategic orientations of a firm, including market orientation, technology orientation (Mu \& Di Benedetto, 2011) [29], entrepreneurial orientation (Mu \& Di Benedetto, 2011; Li et al., 2008) [29] [30] and network orientation (Mu \& Di Benedetto, 2011; Park \& Rhee, 2013) [29] [31] plays a vital role in the commercialization of novel innovations.

Zahra and Nielsen (2002) [32] examined the impact of using internal and external sources on the successful commercialization of technology. They employed four scales in their study to measure the commercialization of technology including: 1) the number of new products; 2) the number of new fundamental 
products; 3) the number of patents; and 4) the speed of commercialization of technology. Further, Park and Rhee (2013) [31] investigated the mediating role of technology commercialization between the types of network and business performance. The commercialization of technology in their study reflects the extent to which an enterprise effectively utilizes patents and know-how to introduce products to the market, through modifying the three items used by $\mathrm{Za}$ hra and Nielsen (2002) [32] and Li et al. (2008) [30]. The scales consist of: 1) our company effectively uses all its patents and know-how; and 2) our company quickly developed a large number of products and introduces to the market; and 3) new products developed by our company have a brighter future market.

Park and Ryu (2015) [26] conducted a study to examine the impact of R\&D capability and learn the capabilities of SMEs entrepreneurs on technology commercialization. In their study, the commercialization of technology refers to the extent to which the firm is capable of transferring patents and know-how to products (Zahra and Nielsen, 2002) [32]. Moreover, Mu and Di Benedetto (2011) [29] studied the effect of strategic orientation (market orientation, technology orientation, entrepreneurial orientation, and network orientation) on the commercialization of a new product. They have used three indicators to measure the performance of new product commercialization: the new product novelty (adapted by Luca and Atuahene-Gima, 2007) [33], the New product advantage (adapted from Song and Parry, 1997; Gatignon and Xuereb, 1997) [34] [35] and the number of new products introduced into the market.

Narver et al. (2004) [11] stated that market orientation consists of two essential behavioral dimensions, including proactive market orientation and responsive market orientation. The proactive market orientation is an attempt to understand and meet the latent needs of customers, while responsive market orientation is an attempt to understand and meet the customer's expressed needs. The expressed needs may include latent and expressed solutions. Here, the needs and solutions expressed by customers defined as needs and solutions that customers are aware of and can therefore express.

\subsection{Knowledge Management Orientation}

Many managers consider knowledge management to be a process that enables organizations to use knowledge assets for creating value (Goh, 2004) [36], leading to the improvement of business performance (Narver \& Slater, 1990) [37]. Knowledge management focuses on important knowledge throughout the organization (Sabherwal \& Becerra-Fernandez, 2003) [38]. Leonard (1998) [39] showed that companies with larger knowledge production and management capacity have a higher innovation capacity.

A firm that uses more knowledge management behaviors and methods are likely to have a knowledge management orientation (Darroch \& McNaughton, 2003) [40]. A strong knowledge management orientation provides the basis of knowledge, enabling the firm to effectively interpret data on external producers 
and events (Wang et al., 2009) [41]. Lin et al. (2015) [42] showed that functional cooperation through knowledge creation provides new opportunities for technology commercialization. Frishammar et al. (2012) [4] studied manufacturing companies in Sweden and showed that knowledge integration that resulted from the usual activities of product commercialization and development allowed them to adapt their technologies to the market (i.e., these activities were critical factors of technology commercialization). Thus:

Hypothesis 1: Knowledge management orientation has a positive effect on product commercialization.

\subsection{Market Orientation}

Market orientation embodies the classic marketing principle that firms need to stay close to their customers. It emphasizes the need for the entire organization to generate, disseminate, and respond to information related to customer needs/preferences and the competition ( $\mathrm{Mu} \&$ Di Benedetto, 2011) [29]. More specifically, it is defined as "the degree to which the business unit obtains and uses information from customers, develops a strategy which will meet customer needs, and implements that strategy by being responsive to customers' needs and wants" (Ruekert, 1992, p. 228) [43]. The NPD process under a market orientation is an outside-in process that focuses on meeting customer needs and delivering superior value ( $\mathrm{Mu}, 2015)$ [44].

While there are different interpretations of market orientation (Day, 1994; Kohli \& Jaworski, 1990; Narver \& Slater, 1990) [10] [37] [45], they all focus on the market data, activities related to customers and competitors, and coordination between units, especially knowledge acquisition, knowledge sharing, and behavioral accountability. The successful commercialization of new products necessitates products that meet the market needs effectively. Products introduced by companies with a market orientation are more likely to bring about customer satisfaction than competitors' products (Ketchen et al., 2007; Paladino, 2007) [46] [47]. Thus, market orientation increases new product commercialization by considering customer needs continuously with an emphasis on the effective use of market data (Atuahene-Gima et al., 2005; Han et al., 1998; Langerak et al., 2004) [48] [49] [50].

Further, market orientation has a positive effect on firm performance, perhaps by acting as a stimulus for satisfying customer needs (Langerak, 2003; Li et al., 2008; Schindehutte et al., 2008) [9] [30] [50]. Hammond et al. (2006) [51] stated that a high level of market orientation leads to the higher ability of organizations to achieve their goals. Thus, a firm needs market orientation more than other strategic orientations to achieve success. Zahra (2008) [52] found a positive relationship between market orientation and firm performance, although entrepreneurial behavior may be needed in industries with more complicated technologies. Voss and Voss (2000) [53] indicated that the dependency between market orientation and performance differs based on the type of performance. Paladino 
(2007) [47] proved that those looking for high financial performance and customer value must focus on market orientation development. Yang et al. (2012) [54] studied whether market orientation and technology orientation affect innovation performance by different degrees. Muand Di Benedetto (2011) [29] used the Narverand Slater (1990) [37] measure to prove that market orientation has a supportive effect on new product commercialization. Atuahene-Gima et al. (2005) [48] showed the effect of responsive and proactive market orientations on NPD performance. Thus:

Hypothesis 2: A proactive market orientation has a positive effect on product commercialization.

Hypothesis 3: A responsive market orientation has a positive effect on product commercialization.

\subsection{The Mediating Role of Market Orientation}

The knowledge management orientation of a firm affects the value of market orientation efforts (Day, 1994) [45]. A lack of knowledge management orientation weakens the effectiveness of production, release of external information into the market, and use of information to respond to the market. On the contrary, organizations must have a supportive culture of knowledge sharing to implement knowledge management activities successfully (Park \& Kim, 2005) [55]. The culture must be considered at the time of introducing new knowledge activities because this affects the acceptance of such activities in organizations (Lai \& Lee, 2007). Market orientation reflects a culture with organizational learning behaviors that aim to create and maintain profitable relations with customers (Olavarrieta \& Friedmann, 2008) [56]. Hence, a positive relationship between a market-oriented culture and the knowledge resources of an organization exists (Day, 1994) [45].

Ferraresi et al. (2012) [57] studied data on 241 Brazilian companies and showed a positive relationship between effective knowledge management and market orientation. Although no direct effect of knowledge management on creativity and performance was found, a positive effect was shown when market orientation was used as a mediator in such relations. Wang et al. (2009) [41] studied the relationships among knowledge management orientation, market orientation, and firm performance. The components of organizational memory, knowledge sharing, knowledge absorption, and knowledge acceptance used to measure knowledge management orientation had a positive effect on three components of market orientation, namely production, transfer, and responding to information. In addition, Wang et al. (2009) [41] showed the positive effect of market orientation on performance and the mediating role of market orientation in the relationship between knowledge management orientation and performance. Darroch and McNaughton (2003) [40] studied 443 companies in the production and service industries and raised knowledge management orientation as a distinguishable ability supporting the creation of sustainable competitive advantage 
such as innovation. Thus, their findings show that firms with a knowledge management orientation outperform market-oriented firms. Thus:

Hypothesis 4: Knowledge management orientation has a positive effect on product commercialization through a proactive market orientation.

Hypothesis 5: Knowledge management orientation has a positive effect on product commercialization through a responsive market orientation.

While strategic orientation can be an important predictor for NPD, taking a strategic orientation alone is insufficient and a better understanding of the probabilities is necessary. Nonetheless, market orientation and entrepreneurial orientation have a positive relation with NPD (Mu et al., 2017) [58]. Several studies have been conducted on commercialization in Iran such as the commercialization of inventions (Zare \& Mirjalili, 2013; Migonouri \& Ahmadi, 2012) [59] [60]. Based on the literature review and research background, Figure 1 presents the conceptual framework and model used in this study.

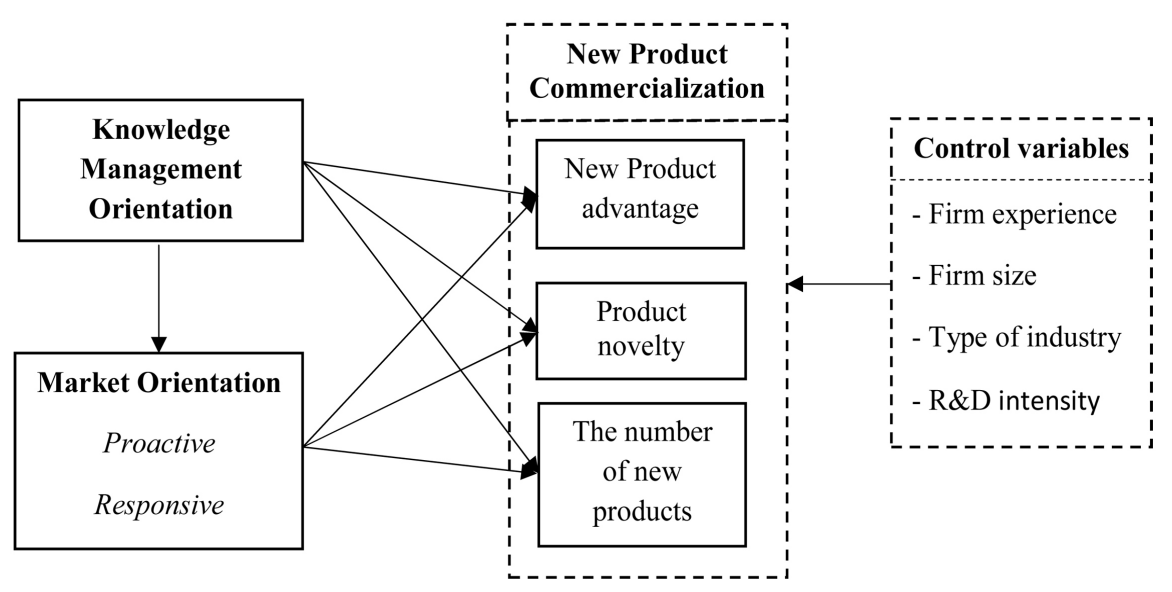

Figure 1. Conceptual model.

\section{Research Methodology}

The population of this study included active manufacturing companies in different industries in Iran. The number of such companies was about 88,110 based on the Behinyab website. the questionnaire was designed based on literatures (Table 1) and sent to managers of 700 firms in various industries including plastic, steel manufacturing, construction, machines and equipment, stone industries, mine, and Nano industries. Of these, 298 companies responded. Finally, due to missing data, our final samples were 252 manufacturing firms in Iran (response rate: $36 \%$ ). All measures for variables have been derived from previous studies and evaluated on a six-point Likert scale (Table 1).

Product commercialization: This variable is based on the new product commercialization indicators used by $\mathrm{Mu}$ and Di Benedetto (2011) [29] in which is included the number of new products introduced to the market during the past five years as well as their novelty and competitive advantages (Darroch \& McNaughton, 2003) [40]. 
Knowledge management orientation: Knowledge management is the process of creating, releasing, and using the knowledge inside and among organizations (Darroch \& McNaughton, 2003) [40]. Following Darrochand McNaughton (2003) [40], we considered three dimensions of knowledge management orientation: knowledge acquisition, knowledge sharing, and knowledge accountability.

Market orientation: This refers to the relation between the firm's business strategy and the hidden and expressed needs of target customers (Slater \& Narver, 1998) [61]. Following Narver et al. (2004) [11], the two dimensions of proactive and responsive market orientations were used to measure the market.

In addition, four variables were used as control variables:

1) The experience of a firm affects its ability to learn and mobilize resources. Older companies may have more experience in introducing new products to the market (Mu \& Di Benedetto, 2011) [29]. The experience of a firm was measured by the number of years a company had participated in the business.

2) Firm size also has a considerable effect on the decisions of companies because it is related to their abilities to exploit current competencies, produce new products, and promote innovations (Chandy \& Tellis, 2000; Mu et al., 2017) [58] [62]. Large companies may allocate more resources to customer relationship management, marketing studies, and R\&D. The number of employees was used to measure firm size.

3) The R\&D intensity in a company is a large driving force behind product commercialization (Day, 1994; Kleinschmidt et al., 2007) [45] [63]. Thus, its effect was controlled for through the budget of $R \& D$ activities to total sales.

4) The type of industry can affect the technological opportunities of companies and thus the number of new products introduced to the market. It can also affect product profitability, the success rate of new product commercialization, customer satisfaction with new products, and the commercialization speed of new products (Gatignon \& Xuereb, 1997; Song \& Parry, 1997) [35] [34]. Furthermore, the sample distribution based on industry type is shown in Figure 2. It is noteworthy that the largest number responded samples are active in the plastic industry and we have the least number in mines.

Table 1. Measures for variables.

\begin{tabular}{|c|c|c|c|}
\hline Ref. & & Measure & Variable \\
\hline \multirow{3}{*}{$\begin{array}{l}\text { Darroch \& McNaughton } \\
\text { (2003) }\end{array}$} & 6 items & Knowledge acquisition & \multirow{3}{*}{$\begin{array}{l}\text { Knowledge management } \\
\text { orientation }\end{array}$} \\
\hline & 5 items & Knowledge dissemination & \\
\hline & 6 items & Knowledge accountability & \\
\hline \multirow{2}{*}{ Narver et al. (2004) } & 8 items & Proactive & \multirow{2}{*}{$\begin{array}{l}\text { Market } \\
\text { orientation }\end{array}$} \\
\hline & 7 items & Responsive & \\
\hline \multirow{3}{*}{$\begin{array}{l}\text { Mu \& Di Benedetto } \\
\text { (2011) }\end{array}$} & 1 items & Number of new products & \multirow{3}{*}{$\begin{array}{l}\text { New product } \\
\text { commercialization } \\
\text { performance }\end{array}$} \\
\hline & 5 items & Product novelty & \\
\hline & 6 items & New product advantage & \\
\hline
\end{tabular}




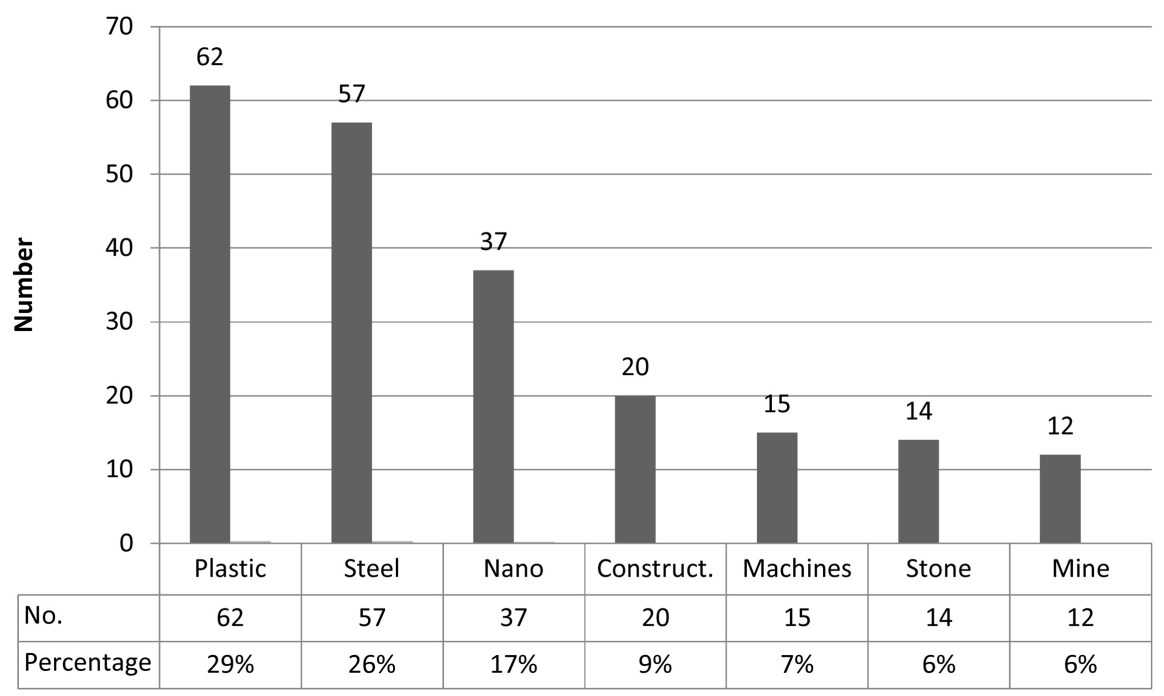

Figure 2. Data sample distribution based on the type of industry.

\section{Data Analysis and Research Findings}

The validity of the measurement tool used in this study was studied in terms of face validity, content validity, and structural validity. To study the simple validity of the variables, a model was designed for each variable. The values of the factor loadings and AVE were more than 0.5 and the CR value was more than 0.7. The goodness-of-fit indicators of each model are as follows: product commercialization $\chi^{2}(\mathrm{n}=252, \mathrm{df}=19)=46.24, \mathrm{P}=0.000$, RMSEA $=0.075$; knowledge management orientation $\chi^{2}(\mathrm{n}=252, \mathrm{df}=24)=70.34, \mathrm{P}=0.000$, RMSEA $=$ 0.088 ; and market orientation $\chi^{2}(\mathrm{n}=252, \mathrm{df}=19)=28.75, \mathrm{P}=0.069$, RMSEA $=$ 0.045 .

Table 2 presents the correlation analysis. Comparing the average dimensions of knowledge management orientation and market orientation showed that the studied companies were mostly market-oriented than knowledge management-oriented. Furthermore, the lower average of proactive market orientation $(\mu=4.41)$ than responsive market orientation $(\mu=4.44)$ indicated that the sample companies responded to the expressed needs of customers more than their hidden needs. Comparing the average variables related to the knowledge management process showed that knowledge sharing $(\mu=3.90)$ among these companies was relatively low. Comparing the correlation among the variables showed that the dimensions of knowledge management orientation (knowledge acquisition, sharing, and accountability) had a high positive correlation. This was also true for the dimensions of market orientation.

Table 3 shows the results of testing Hypothesis 1. The relationships between the independent variable of knowledge management orientation and dependent variables of product advantage, product novelty, and the number of new products were tested in two models. Model 1 shows the results for the state including only the control variables. By neutralizing the effect of such variables in model 2, it was observed that when knowledge management orientation was added into 
Table 2. Descriptive statistics and correlations.

\begin{tabular}{|c|c|c|c|c|c|c|c|c|c|c|c|c|c|c|}
\hline & Variables & Mean & $\begin{array}{l}\text { Standard } \\
\text { deviation }\end{array}$ & 1 & 2 & 3 & 4 & 5 & 6 & 7 & 8 & 9 & 10 & 11 \\
\hline 1 & $\begin{array}{c}\text { Product } \\
\text { advantage }\end{array}$ & 4.89 & 0.83 & 1 & & & & & & & & & & \\
\hline 2 & $\begin{array}{l}\text { Product } \\
\text { novelty }\end{array}$ & 4.04 & 1.07 & $0.252^{\star *}$ & 1 & & & & & & & & & \\
\hline 3 & $\begin{array}{l}\text { No. of new } \\
\text { products }\end{array}$ & 2.08 & 1.32 & -0.004 & 0.114 & 1 & & & & & & & & \\
\hline 4 & $\begin{array}{l}\text { Knowledge } \\
\text { acquisition }\end{array}$ & 4.20 & 1.06 & $0.340^{* *}$ & $0.280^{* *}$ & $0.148^{*}$ & 1 & & & & & & & \\
\hline 5 & $\begin{array}{c}\text { Knowledge } \\
\text { dissemination }\end{array}$ & 3.90 & 1.11 & $0.330^{* *}$ & $0.309^{* *}$ & $0.140^{*}$ & $0.616^{* *}$ & 1 & & & & & & \\
\hline 6 & $\begin{array}{l}\text { Knowledge } \\
\text { accountability }\end{array}$ & 4.13 & 1.09 & $0.403^{* *}$ & $0.357^{\star *}$ & $0.141^{\star}$ & $0.595^{\star *}$ & $0.599^{\star *}$ & 1 & & & & & \\
\hline 7 & $\begin{array}{c}\text { Proactive market } \\
\text { orientation }\end{array}$ & 4.41 & 0.98 & $0.357^{* *}$ & $0.181^{\star *}$ & $0.212^{\star *}$ & $0.543^{* *}$ & $0.467^{\star *}$ & $0.582^{\star *}$ & 1 & & & & \\
\hline 8 & $\begin{array}{l}\text { Responsive } \\
\text { market } \\
\text { orientation }\end{array}$ & 4.44 & 0.94 & $0.438^{* *}$ & $0.219^{* *}$ & $0.167^{*}$ & $0.620^{* *}$ & $0.510^{* *}$ & $0.588^{* *}$ & $0.710^{* *}$ & 1 & & & \\
\hline 9 & Firm experience & 2.33 & 0.85 & -0.007 & -0.077 & 0.106 & $0.150^{*}$ & $0.132^{*}$ & 0.053 & 0.122 & $0.131^{*}$ & 1 & & \\
\hline 10 & Firm size & 3.4 & 1.26 & 0.027 & -0.057 & $0.237^{\star *}$ & 0.108 & 0.050 & 0.039 & 0.114 & 0.102 & $0.569^{* *}$ & 1 & \\
\hline 11 & R\&D expenses & 2.82 & 0.91 & $0.140^{*}$ & $0.192^{\star *}$ & 0.064 & $0.219^{* *}$ & $0.291^{\star *}$ & $0.354^{* *}$ & $0.258^{* *}$ & $0.241^{\star *}$ & 0.006 & -0.042 & 1 \\
\hline
\end{tabular}

${ }^{*} \mathrm{P}<0.01,{ }^{*} \mathrm{P}<0.05$. 
Table 3. Hierarchical regressions (knowledge management orientation).

\begin{tabular}{|c|c|c|c|c|c|c|c|c|c|c|c|c|c|}
\hline \multirow{3}{*}{ Variable } & \multicolumn{4}{|c|}{ Product Advantage } & \multicolumn{4}{|c|}{ Product Novelty } & \multicolumn{4}{|c|}{ No. of New Products } & \multirow{3}{*}{ VIF } \\
\hline & \multicolumn{2}{|c|}{ Model 1} & \multicolumn{2}{|c|}{ Model 2} & \multicolumn{2}{|c|}{ Model 3} & \multicolumn{2}{|c|}{ Model 4} & \multicolumn{2}{|c|}{ Model 5} & \multicolumn{2}{|c|}{ Model 6} & \\
\hline & $\beta$ & $\mathrm{t}$ & $\beta$ & $\mathrm{t}$ & $\beta$ & $\mathrm{t}$ & $\beta$ & $\mathrm{t}$ & $\beta$ & $\mathrm{t}$ & $\beta$ & $\mathrm{t}$ & \\
\hline Firm experience & -0.033 & -0.421 & -0.071 & -0.992 & -0.091 & -1.192 & -0.119 & -1.630 & -0.045 & -0.573 & -0.059 & -0.748 & 1.278 \\
\hline No. of employees & -0.060 & -0.785 & -0.083 & -1.184 & 0.105 & 1.391 & 0.088 & 1.221 & $0.145^{\star}$ & 1.864 & $0.138^{*}$ & 1.772 & 1.244 \\
\hline$R \& D$ expenses & $0.143^{*}$ & 1.965 & 0.012 & 0.178 & $0.194^{* * *}$ & 2.709 & 0.098 & 1.363 & 0.093 & 1.254 & 0.056 & 0.726 & 1.128 \\
\hline Steel manufacturing & -0.093 & -1.125 & -0.090 & -1.181 & -0.005 & -0.059 & -0.002 & -0.027 & -0.070 & -0.818 & -0.071 & -0.839 & 1.460 \\
\hline $\begin{array}{l}\text { Construction } \\
\text { industries }\end{array}$ & -0.087 & -1.145 & -0.069 & -0.983 & -0.033 & -0.446 & -0.020 & -0.274 & 0.060 & 0.765 & 0.060 & 0.770 & 1.231 \\
\hline $\begin{array}{l}\text { Machines and } \\
\text { equipment }\end{array}$ & $-0.157^{\star *}$ & -2.116 & $-0.120^{*}$ & -1.752 & 0.025 & 0.344 & 0.053 & 0.757 & -0.120 & -1.555 & -0.109 & -1.418 & 1.174 \\
\hline Stone industries & $-0.140^{*}$ & -1.907 & -0.099 & -1.467 & 0.008 & 0.112 & 0.038 & 0.555 & 0.000 & -0.004 & 0.012 & 0.152 & 1.146 \\
\hline Mine industries & -0.034 & -0.466 & -0.031 & -0.464 & 0.113 & 1.572 & $0.115^{*}$ & 1.681 & $0.139^{*}$ & 1.860 & $0.143^{*}$ & 1.916 & 1.127 \\
\hline Nano industries & -0.094 & -1.113 & -0.099 & -1.280 & 0.109 & 1.312 & 0.105 & 1.329 & 0.099 & -1.150 & -0.101 & -1.181 & 1.517 \\
\hline $\begin{array}{l}\text { Knowledge } \\
\text { management } \\
\text { orientation }\end{array}$ & & & $0.428^{\star * *}$ & 6.350 & & & $0.317^{\star * *}$ & 4.574 & & & 0.119 & 1.573 & \\
\hline $\mathrm{R}$ & \multicolumn{2}{|c|}{0.231} & \multicolumn{2}{|c|}{0.461} & \multicolumn{2}{|c|}{0.288} & \multicolumn{2}{|c|}{0.412} & \multicolumn{2}{|c|}{0.274} & \multicolumn{2}{|c|}{0.295} & \\
\hline R Square & \multicolumn{2}{|c|}{0.053} & \multicolumn{2}{|c|}{0.212} & \multicolumn{2}{|c|}{0.083} & \multicolumn{2}{|c|}{0.170} & \multicolumn{2}{|c|}{0.075} & \multicolumn{2}{|c|}{0.087} & \\
\hline R Square change & \multicolumn{2}{|c|}{0.053} & \multicolumn{2}{|c|}{0.159} & \multicolumn{2}{|c|}{0.083} & \multicolumn{2}{|c|}{0.087} & \multicolumn{2}{|c|}{0.075} & \multicolumn{2}{|c|}{0.012} & \\
\hline Adjusted R Square & \multicolumn{2}{|c|}{0.011} & \multicolumn{2}{|c|}{0.173} & \multicolumn{2}{|c|}{0.042} & \multicolumn{2}{|c|}{0.128} & 0.0 & 31 & 0.0 & 38 & \\
\hline F statistics & 1.2 & & 5.3 & & 2.0 & & 4.09 & & 1.6 & 594 & 1.7 & 84 & \\
\hline Sig. & 0.2 & & 0.0 & & 0.0 & & 0.00 & & 0.0 & 93 & 0.0 & 66 & \\
\hline
\end{tabular}

$\mathrm{n}=252,{ }^{*} \mathrm{P}<0.1,{ }^{* * \mathrm{P}}<0.05,{ }^{* * * \mathrm{P}}<0.01$.

Thus, Hypotheses 2 was supported.

Table 5 presents the results of testing Hypothesis 3, showing that almost 20\% of the product advantage dispersion (change in the coefficient of determination = $0.197, \mathrm{P}<0.01$ ), $3.5 \%$ of the product novelty dispersion (change in the coefficient of determination $=0.035, \mathrm{P}<0.01$ ), and $2 \%$ of the dispersion in the number of new products (change in the coefficient of determination $=0.020, \mathrm{P}<$ $0.01)$ were related to the responsive market orientation. As shown, the responsive market orientation had a significant relation with product advantage $(\mathrm{P}<$ $0.01, t=7.245)$, product novelty $(P<0.01, t=2.813)$, and the number of new products $(\mathrm{P}<0.01, \mathrm{t}=2.023)$. Thus, Hypothesis 3 were supported.

Figure 3 presents the results related to testing Hypotheses 4 and 5. The shapes in rows 1 and 2 relate to Hypothesis 4 . As can be seen, when studying the effect of knowledge management orientation on product advantage and product novelty through the proactive market orientation, no effect of the proactive market orientation on product advantage $(\mathrm{t}=0.93<1.96)$ or product novelty $(\mathrm{t}=$ $-1.54>-1.96)$ was found. Thus, the proactive market orientation does not have 
Table 4. Hierarchical regressions (proactive market orientation).

\begin{tabular}{|c|c|c|c|c|c|c|c|c|c|c|c|c|c|c|}
\hline \multirow{3}{*}{ Variable } & \multicolumn{4}{|c|}{ Product Advantage } & \multicolumn{4}{|c|}{ Product Novelty } & \multicolumn{4}{|c|}{ No. of New Products } & \multicolumn{2}{|c|}{ VIF } \\
\hline & \multicolumn{2}{|c|}{ Model 1} & \multicolumn{2}{|c|}{ Model 2} & \multicolumn{2}{|c|}{ Model 3} & \multicolumn{2}{|c|}{ Model 4} & \multicolumn{2}{|c|}{ Model 5} & \multicolumn{2}{|c|}{ Model 6} & \multicolumn{2}{|c|}{-Model 1 Model 2} \\
\hline & $\beta$ & $\mathrm{t}$ & $\beta$ & $\mathrm{t}$ & $\beta$ & $\mathrm{t}$ & $\beta$ & $\mathrm{t}$ & $\beta$ & $\mathrm{t}$ & $\beta$ & $\mathrm{t}$ & & \\
\hline Firm experience & -0.033 & -0.421 & -0.066 & -0.906 & -0.091 & -1.192 & -0.105 & -1.383 & -0.045 & -0.573 & -0.066 & -0.837 & 1.278 & 1.288 \\
\hline No. of employees & -0.060 & -0.785 & -0.069 & -0.959 & 0.107 & 1.391 & 0.101 & 1.353 & $0.145^{*}$ & 1.864 & $0.140^{*}$ & 1.813 & 1.244 & 1.245 \\
\hline R\&D expenses & $0.143^{*}$ & 1.965 & 0.056 & 0.794 & $0.194^{* * *}$ & 2.709 & $0.158^{\star *}$ & 2.157 & 0.093 & 1.254 & 0.053 & 0.707 & 1.128 & 1.194 \\
\hline $\begin{array}{l}\text { Steel } \\
\text { manufacturing }\end{array}$ & -0.093 & -1.125 & -0.115 & -1.478 & -0.005 & -0.059 & -0.014 & -0.173 & -0.070 & -0.818 & -0.059 & -0.702 & 1.460 & 1.464 \\
\hline $\begin{array}{l}\text { Construction } \\
\text { industries }\end{array}$ & -0.087 & -1.145 & -0.074 & -1.032 & -0.033 & -0.446 & -0.028 & -0.375 & 0.060 & 0.765 & 0.076 & 0.972 & 1.231 & 1.232 \\
\hline $\begin{array}{l}\text { Machines \& } \\
\text { equipment }\end{array}$ & $-0.157^{\star *}$ & -2.116 & $-0.140^{* *}$ & -2.005 & 0.025 & 0.344 & 0.032 & 0.444 & -0.120 & -1.555 & -0.104 & -1.363 & 1.174 & 1.177 \\
\hline Stone industries & $-0.140^{*}$ & -1.907 & $-0.130^{*}$ & -1.886 & 0.008 & 0.112 & 0.012 & 0.170 & 0.000 & -0.004 & 0.012 & 0.155 & 1.146 & 1.146 \\
\hline Mine industries & -0.034 & -0.466 & -0.054 & -0.782 & 0.113 & 1.572 & 0.105 & 1.468 & $0.139^{\star}$ & 1.860 & $0.137^{\star}$ & 1.846 & 1.127 & 1.131 \\
\hline Nano industries & -0.094 & -1.113 & -0.088 & -1.107 & 0.109 & 1.312 & 0.112 & 1.354 & -0.099 & -1.150 & -0.085 & -1.000 & 1.517 & 1.517 \\
\hline $\begin{array}{l}\text { Proactive market } \\
\text { orientation }\end{array}$ & & & $0.354^{\star * *}$ & 5.246 & & & $0.148^{\star *}$ & 2.112 & & & $0.164^{\star *}$ & 2.250 & & 1.094 \\
\hline $\mathrm{R}$ & 0.2 & & 0.4 & & 0.2 & & 0.3 & & & 74 & 0.3 & & & \\
\hline R Square & 0.0 & & 0.1 & & 0.0 & & 0.1 & & & & 0.0 & & & \\
\hline $\mathrm{R}$ Square change & 0.0 & & 0.1 & & 0.0 & & 0.0 & & & & 0.0 & & & \\
\hline Adjusted R Square & 0.0 & & 0.12 & & 0.0 & & 0.0 & & & 31 & 0.0 & & & \\
\hline F statistics & 1.2 & & 4.0 & & 2.0 & & 2.2 & & & 94 & 2.0 & & & \\
\hline Sig. & 0.2 & & 0.0 & & 0.0 & & 0.0 & & & 93 & 0.0 & 29 & & \\
\hline
\end{tabular}

$\mathrm{n}=252,{ }^{*} \mathrm{P}<0.1,{ }^{* * \mathrm{P}}<0.05,{ }^{* * *} \mathrm{P}<0.01$.

a mediating role in the relationships between knowledge management orientation and product advantage or between knowledge management orientation and product novelty. Thus, Hypotheses 4 was rejected.

Row 3 of Figure 3 shows that when studying the effect of knowledge management orientation on product advantage through the responsive market orientation, no effect of knowledge management orientation on product advantage $(\mathrm{t}=$ $0.71<1.96)$ was found. On the contrary, the relationships between knowledge management orientation and responsive market orientation and between responsive market orientation and product advantages were not confirmed. Thus, Hypothesis 5 was supported. In row 4 of the same figure, the relationship between knowledge management orientation and product novelty was studied through the responsive market orientation. As can be seen, the effect of responsive market orientation on product novelty $(\mathrm{t}=-1.40>-1.96)$ was not supported. Thus, the responsive market orientation does not have a mediating role in the relationship between knowledge management orientation and product novelty. 
Table 5. Hierarchical regressions (responsive market orientation).

\begin{tabular}{|c|c|c|c|c|c|c|c|c|c|c|c|c|c|c|}
\hline \multirow{3}{*}{ Variable } & \multicolumn{4}{|c|}{ Product Advantage } & \multicolumn{4}{|c|}{ Product Novelty } & \multicolumn{4}{|c|}{ No. of New Products } & \multicolumn{2}{|c|}{ VIF } \\
\hline & \multicolumn{2}{|c|}{ Model 1} & \multicolumn{2}{|c|}{ Model 2} & \multicolumn{2}{|c|}{ Model 3} & \multicolumn{2}{|c|}{ Model 4} & \multicolumn{2}{|c|}{ Model 5} & \multicolumn{2}{|c|}{ Model 6} & \multirow{2}{*}{$\begin{array}{c}\text { Model } \\
1\end{array}$} & \multirow{2}{*}{ Model 2} \\
\hline & $\beta$ & $\mathrm{t}$ & $\beta$ & $\mathrm{t}$ & $\beta$ & $\mathrm{t}$ & $\beta$ & $\mathrm{t}$ & $\beta$ & $\mathrm{t}$ & $\beta$ & $\mathrm{t}$ & & \\
\hline Firm experience & -0.033 & -0.421 & -0.101 & -1.442 & -0.091 & -1.192 & -0.120 & -1.580 & -0.045 & -0.573 & -0.071 & -0.898 & 1.278 & 1.302 \\
\hline No. of employees & -0.060 & -0.785 & -0.070 & -1.021 & 0.105 & 1.391 & 0.101 & 1.360 & $0.145^{*}$ & 1.864 & $0.140^{*}$ & 1.818 & 1.244 & 1.244 \\
\hline R\&D expenses & $0.143^{\star}$ & 1.965 & 0.037 & 0.551 & $0.194^{\star \star *}$ & 2.709 & $0.149^{\star *}$ & 2.067 & 0.093 & 1.254 & 0.056 & 0.739 & 1.128 & 1.186 \\
\hline Steel manufacturing & -0.093 & -1.125 & -0.064 & -0.862 & -0.005 & -0.059 & 0.008 & 0.094 & -0.070 & -0.818 & -0.082 & -0.969 & 1.460 & 1.464 \\
\hline $\begin{array}{l}\text { Construction indus- } \\
\text { tries }\end{array}$ & -0.087 & -1.145 & -0.069 & -1.012 & -0.033 & -0.446 & -0.026 & -0.348 & 0.060 & 0.765 & 0.058 & 0.751 & 1.231 & 1.232 \\
\hline $\begin{array}{l}\text { Machines and } \\
\text { equipment }\end{array}$ & $-0.157^{\star *}$ & -2.116 & $-0.125^{\star}$ & -1.881 & 0.025 & 0.344 & 0.039 & 0.537 & -0.120 & -1.555 & -0.116 & -1.525 & 1.174 & 1.179 \\
\hline Stone industries & $-0.140^{*}$ & -1.907 & -0.101 & -1.537 & 0.008 & 0.112 & 0.025 & 0.344 & 0.000 & -0.004 & 0.006 & 0.078 & 1.146 & 1.153 \\
\hline Mine industries & -0.034 & -0.466 & -0.045 & -0.693 & 0.113 & 1.572 & 0.108 & 1.532 & $0.139^{*}$ & 1.860 & $0.131^{*}$ & 1.765 & 1.127 & 1.128 \\
\hline Nano industries & -0.094 & -1.113 & -0.067 & -0.891 & 0.109 & 1.312 & 0.120 & 1.470 & -0.099 & -1.150 & -0.100 & -1.174 & 1.517 & 1.520 \\
\hline $\begin{array}{l}\text { Responsive market } \\
\text { orientation }\end{array}$ & & & $0.465^{\star \star \star}$ & 7.245 & & & $0.196^{* * *}$ & 2.813 & & & $0.149^{* *}$ & 2.023 & & 1.097 \\
\hline $\mathrm{R}$ & 0.2 & & 0.5 & & 0.28 & & 0.34 & & 0.2 & 74 & 0.3 & 08 & & \\
\hline R Square & 0.0 & & 0.2 & & 0.08 & & 0.11 & & 0.0 & 75 & 0.0 & & & \\
\hline $\mathrm{R}$ Square change & 0.0 & & 0.1 & & 0.08 & & 0.03 & & 0.0 & 75 & 0.0 & & & \\
\hline Adjusted R Square & 0.0 & & 0.2 & & 0.0 & & 0.07 & & 0.0 & 31 & 0.0 & & & \\
\hline F statistics & 1.2 & & 6.6 & & 2.02 & & 2.67 & & 1.6 & 994 & 1.9 & & & \\
\hline Sig. & 0.2 & & 0.0 & & 0.03 & & 0.00 & & 0.0 & 93 & 0.0 & 40 & & \\
\hline
\end{tabular}

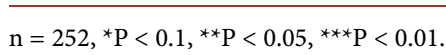

\section{Discussion and Conclusions}

We studied product commercialization in three aspects: product advantage, product commercialization, and the number of new products introduced to the market. The findings showed that knowledge management orientation affects the advantage and freshness of products. In addition, the responsive and proactive market orientations affect all the dimensions of commercialization. In other words, these two factors cause the presentation of products that are fresh for both the firm and the industry, add new customers, and satisfy the needs not already identified. Products that have higher quality than competitors' products attract more customer satisfaction. In a knowledge-based management firm, a strong basis of knowledge enables the company to process and interpret the data on external events and procedures (Wang et al., 2009) [41]. A knowledge-based management firm releases market data on the whole organization and responds to it. Such a firm is also flexible and opportunistic, and it has strong marketing programs for changing products, processes, and strategies (Darroch \& McNaughton, 2003) [40]. On the contrary, the business strategy of a market-oriented firm is sufficiently related to the expressed and hidden needs of target customers (Slater \& Narver, 1998) [61]. By providing products that meet customer needs 

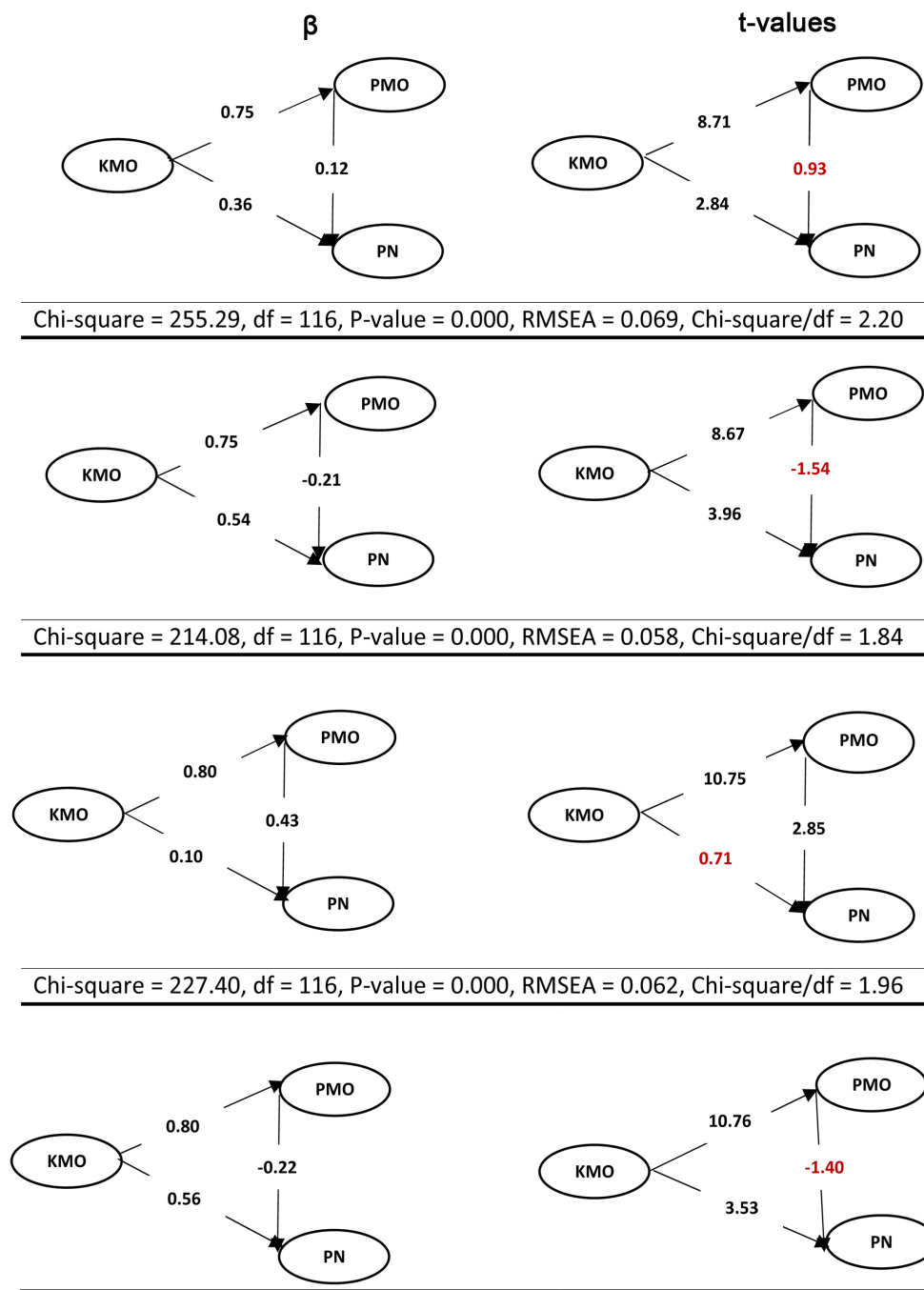

Chi-square $=200.53, \mathrm{df}=116, \mathrm{P}$-value $=0.000, \mathrm{RMSEA}=0.054$, Chi-square $/ \mathrm{df}=1.72$

Figure 3. Structural Equation Modeling (SEM) for Hypotheses (4) and (5). KMO: knowledge management orientation; RMO: responsive market orientation; PMO: proactive market orientation; PA: product advantage; PN: product novelty.

(Day, 1994) [45], superior value is continuously created (Narver \& Slater, 1990) [37]. This result is consistent with the results of Lin et al. (2015) [42], Frishammar et al. (2012) [4], and Mu and Di Benedetto (2011) [29] on the relationships among commercialization, knowledge management orientation, and the market. Their findings showed that only the responsive market orientation has a mediating role in the relationship between knowledge management orientation and product advantage.

According to our findings, knowledge management orientation and market orientation can be considered to be appropriate predictor variables for product commercialization. These are considered to be the strategic assets of an organization prescribing the interactions of organizational members as well as the interactions of the organization with the market, competitors, and customers and providing a context for organizations to present products according to market 
needs to achieve the desired commercialization (Noble et al., 2002) [64]. Such strategic assets reflect a company's deep set of values and beliefs beyond individual attitudes, unify the available resources and abilities of the organization, and convert them into an integrated whole (Calantone \& Griffith, 2007) [65]. Thus, they lead to superior firm performance (Covin \& Slevin, 1989) [66]. Competitors can imitate these orientations. Thus, organizations should use such orientations.

Knowledge management requires companies to show dominant behavior. Firstly, a knowledge-based management firm collects implicit data and knowledge from within and outside the organization and provides access to a broad range of financial data. Secondly, a knowledge-based management firm balances formal and informal communication methods and uses techniques such as counseling and coaching as well as technologies such as remote conferencing and video conferencing. Finally, a knowledge-based management firm is responsible for publishing data on the market and technology and must develop and implement marketing programs effectively. In addition, it is opportunistic and flexible when faced with a change in products, processes, and strategies.

Furthermore, firms must analyze the main processes of the market to be proactive, identify unaware customer needs months or years before competitors, and finally present solutions that respond to these needs. They must focus on customers to be responsive to the market as well as understand customers' needs and satisfy them. In addition, they must measure customer satisfaction continuously.

Finally, future research could study the effectiveness of knowledge management and market orientations on commercialization by using other variables including agility and the presence of database systems. The issues used to measure product commercialization in the background are mainly used to measure innovation and new product performance.

\section{Acknowledgements}

The second author is deeply grateful to the support provided by JSPS KAKENHI grant number $18 \mathrm{~K} 01746$.

\section{Conflicts of Interest}

The authors declare no conflicts of interest regarding the publication of this paper.

\section{References}

[1] UNCTAD (2016) World Investment Report, Geneva.

[2] Allen, R.C. (2012) Technology and the Great Divergence: Global Economic Development Since 1820. Explorations in Economic History, 49, 1-16. https://doi.org/10.1016/j.eeh.2011.09.002

[3] Dorf, R.C. and Worthington, K.K.F. (1987) Models for Commercialization of Technology from Universities and Research Laboratories. Journal of Technology Trans- 
fer, 12, 1-8. https://doi.org/10.1007/BF02371357

[4] Frishammar, J., Lichtenthaler, U. and Rundquist, J. (2012) Identifying Technology Commercialization Opportunities: The Importance of Integrating Product Development Knowledge. Journal of Product Innovation Management, 29, 573-589. https://doi.org/10.1111/j.1540-5885.2012.00926.x

[5] Heslop, L.A., McGregor, E. and Griffith, M. (2001) Development of a Technology Readiness Assessment Measure: The Cloverleaf Model of Technology Transfer. Journal of Technology Transfer, 26, 369-384.

https://doi.org/10.1023/A:1011139021356

[6] Helfat, C., Finkelstein, S., Mitchell, W., Peteraf, M., Singh, H., Teece, D. and Winter, S. (2007) Dynamic Capabilities: Understanding Strategic Change in Organizations. Blackwell, Malden, MA.

[7] Eisenhardt, K.M. and Martin, J.A. (2000) Dynamic Capabilities: What Are They? Strategic Management Journal, 21, 1105-1121. https://doi.org/10.1002/1097-0266(200010/11)21:10/11<1105::AID-SMJ133>3.0.CO;2-E

[8] Teece, D.J. (2007) Explicating Dynamic Capabilities: The Nature and Micro-Foundations of (Sustainable) Enterprise Performance. Strategic Management Journal, 28, 1319-1350. https://doi.org/10.1002/smj.640

[9] Schindehutte, M., Morris, M.H. and Kocak, A. (2008) Understanding MarketDriving Behavior: The Role of Entrepreneurship. Journal of Small Business Management, 46, 4-26. https://doi.org/10.1111/j.1540-627X.2007.00228.x

[10] Kohli, A.K. and Jaworski, B.J. (1990) Market Orientation: The Construct, Research Propositions and Managerial Implications. The Journal of Marketing, 54, 1-18. https://doi.org/10.1177/002224299005400201

[11] Narver, J.C., Slater, S.F. and MacLachlan, D.L. (2004) Responsive and Proactive Market Orientation and New-Product Success. Journal of Product Innovation Management, 21, 334-347. https://doi.org/10.1111/j.0737-6782.2004.00086.x

[12] Colakoglu, U., Culha, O. and Atay, H. (2010) The Effects of Perceived Organizational Support on Employee's Affective Outcomes: Evidence from the Hotel Industry. Tourism and Hospitality Management, 16, 125-150.

[13] Cho, J. and Lee, J. (2013) Development of a New Technology Product Evaluation Model for Assessing Commercialization Opportunities Using Delphi Method and Fuzzy AHP Approach. Expert Systems with Applications, 40, 5314-5330. https://doi.org/10.1016/j.eswa.2013.03.038

[14] Durmuşoğlu, S.S. and Barczak, G. (2011) The Use of Information Technology Tools in New Product Development Phases: Analysis of Effects on New Product Innovativeness, Quality, and Market Performance. Industrial Marketing Management, 40, 321-330. https://doi.org/10.1016/j.indmarman.2010.08.009

[15] Protogerou, A., Caloghirou, Y. and Lioukas, S. (2011) Dynamic Capabilities and Their Indirect Impact on Firm Performance. Industrial Corporate Change, 21, 615 647. https://doi.org/10.1093/icc/dtr049

[16] Harmancioglu, N., Grinstein, A. and Goldma, A. (2010) Innovation and Performance Outcomes of Market Information Collection Efforts: The Role of Top Management Team Involvement. International Journal of Research in Marketing, 27, 33-43. https://doi.org/10.1016/j.ijresmar.2009.09.005

[17] Martin Rojas, R., Garcia Morales, V.J. and Bolivar Ramos, M.T. (2013) Influence of Technological Support, Skills and Competencies, and Learning on Corporate Entrepreneurship in European Technology Firms. Technovation, 33, 417-430. 
https://doi.org/10.1016/j.technovation.2013.08.002

[18] Kim, S.K., Lee, B.G., Park, B.S. and Oh, K.S. (2011) The Effect of R \& D, Technology Commercialization Capabilities and Innovation Performance. Technological and Economic Development of Economy, 17, 563-578. https://doi.org/10.3846/20294913.2011.603481

[19] Wilden, R., Gudergan, S.P., Nielsen, B.B. and Lings, I. (2013) Dynamic Capabilities and Performance: Strategy, Structure and Environment. Long Range Planning, 46, 72-96. https://doi.org/10.1016/j.lrp.2012.12.001

[20] Lew, Y.K. and Sinkovics, R.R. (2013) Practices in Mobile Computing Alliances. In: Harris, S., Kuivalainen, O. and Stoyanova, V., Eds., International Business e New Challenges, New Forms, New Perspectives, Palgrave MacMillan, Houndmill, Basingstoke, UK, 242-261. https://doi.org/10.1057/9781137007742_14

[21] Kock, A., Gemünden, H.G., Salomo, S. and Schultz, C. (2011) The Mixed Blessings of Technological Innovativeness for the Commercial Success of New Products. Journal of Product Innovation Management, 28, 28-43. https://doi.org/10.1111/j.1540-5885.2011.00859.x

[22] Heng, L.H., Rasli, A.M. and Senin, A.A. (2012) Knowledge Determinant in University Commercialization: A Case Study of Malaysia Public University. Procedia-Social and Behavioral Sciences, 40, 251-257. https://doi.org/10.1016/j.sbspro.2012.03.187

[23] Chiang, Y.H. and Shih, H.A. (2011) Knowledge-Oriented Human Resource Configurations, the New Product Development Learning Process and Perceived New Product Performance. The International Journal of Human Resource Management, 22, 3202-3221. https://doi.org/10.1080/09585192.2011.560874

[24] Kostopoulos, K., Papalexandris, A., Papachroni, M. and Ioannou, G. (2011) Absorptive Capacity, Innovation and Financial Performance. Journal of Business Research, 64, 1335-1343. https://doi.org/10.1016/j.jbusres.2010.12.005

[25] Datta, A., Jessup, L. and Reed, R. (2011) Corporate Reputation and the Commercialization of Innovation: Does Reputation Match Reality, and Does Innovation Matter? Technology and Investment, 2, 256-272. https://doi.org/10.4236/ti.2011.24027

[26] Park, T. and Ryu, D. (2015) Drivers of Technology Commercialization and Performance in SMEs: The Moderating Effect of Environmental Dynamism. Management Decision, 53, 338-353. https://doi.org/10.1108/MD-03-2014-0143

[27] Lam, A. (2011) What Motivates Academic Scientists to Engage in Research Commercialization: 'Gold', 'Ribbon' or 'Puzzle'? Research Policy, 40, 1354-1368. https://doi.org/10.1016/j.respol.2011.09.002

[28] Wu, W. (2010) Managing and Incentivizing Research Commercialization in Chinese Universities. The Journal of Technology Transfer, 35, 203-224.

https://doi.org/10.1007/s10961-009-9116-4

[29] $\mathrm{Mu}$, J. and Di Benedetto, C.A. (2011) Strategic Orientations and New Product Commercialization: Mediator, Moderator and Interplay. $R \& D$ Management, 41, 337 359. https://doi.org/10.1111/j.1467-9310.2011.00650.x

[30] Li, Y., Zhao, Y., Tan, J. and Liu, Y. (2008) Moderating Effects of Entrepreneurial Orientation on Market Orientation-Performance Linkage: Evidence from Chinese Small Firms. Journal of Small Business Management, 46, 113-133. https://doi.org/10.1111/j.1540-627X.2007.00235.x

[31] Park, T. and Rhee, J. (2013) Network Types and Performance in SMEs: The Mediating Effects of Technology Commercialization. Asian Journal of Technology Innovation, 21, 290-304. https://doi.org/10.1080/19761597.2013.866311 
[32] Zahra, S.A. and Nielsen, A.P. (2002) Sources of Capabilities, Integration and Technology Commercialization. Strategic Management Journal, 23, 377-398.

https://doi.org/10.1002/smj.229

[33] Luca, L.M.D. and Atuahene-Gima, K. (2007) Market Knowledge Dimensions and Cross-Functional Collaboration: Examining the Different Routes to Product Innovation Performance. Journal of Marketing, 71, 95-112.

[34] Song, X.M. and Parry, M.E. (1997) The Determinants of Japanese New Product Successes. Journal of Marketing Research, 34, 64-76. https://doi.org/10.1177/002224379703400106

[35] Gatignon, H. and Xuereb, J.M. (1997) Strategic Orientation of the Firm and New Product Performance. Journal of Marketing Research, 34, 77-90. https://doi.org/10.1177/002224379703400107

[36] Goh, A. (2004) Enhancing Organizational Performance through Knowledge Innovation: A Proposed Strategic Management Framework. Journal of Knowledge Management Practice, 5, 111-123.

[37] Narver, J.C. and Slater, S.F. (1990) The Effect of a Market Orientation on Business Profitability. The Journal of Marketing, 54, 20-35. https://doi.org/10.1177/002224299005400403

[38] Sabherwal, R. and Becerra-Fernandez, I. (2003) An Empirical Study of the Effect of Knowledge Management Processes at Individual, Group and Organizational Levels. Decision Sciences, 34, 225-260. https://doi.org/10.1111/1540-5915.02329

[39] Leonard, D. (1998) Nascentes do saber-criando e sustentando as fontes de inovação. Fundação Getúlio Vargas, Rio de Janeiro.

[40] Darroch, J. and McNaughton, R. (2003) Beyond Market Orientation: Knowledge Management and the Innovativeness of New Zealand Firms. European Journal of Marketing, 37, 572-593. https://doi.org/10.1108/03090560310459096

[41] Wang, C.L., Hult, G.T.M., Ketchen Jr., D.J. and Ahmed, P.K. (2009) Knowledge Management Orientation, Market Orientation and Firm Performance: An Integration and Empirical Examination. Journal of Strategic Marketing, 17, 99-122. https://doi.org/10.1080/09652540902879326

[42] Lin, Y., Wang, Y. and Kung, L. (2015) Influences of Cross-Functional Collaboration and Knowledge Creation on Technology Commercialization: Evidence from HighTech Industries. Industrial Marketing Management, 49, 128-138. https://doi.org/10.1016/j.indmarman.2015.04.002

[43] Ruekert, R.W. (1992) Developing a Market Orientation: An Organizational Strategy Perspective. International Journal of Marketing, 9, 225-245. https://doi.org/10.1016/0167-8116(92)90019-H

[44] Mu, J. (2015) Marketing Capability, Organizational Adaptation and New Product Development Performance. Industrial Marketing Management, 49, 151-166. https://doi.org/10.1016/j.indmarman.2015.05.003

[45] Day, G.S. (1994) The Capabilities of Market-Driven Organizations. Journal of Marketing, 38, 37-52. https://doi.org/10.1177/002224299405800404

[46] Ketchen, D.J., Hult, G.T.M. and Slater, S.F. (2007) Toward Greater Understanding of Market Orientation and the Resource-Based View. Strategic Management Journal, 28, 961-964. https://doi.org/10.1002/smj.620

[47] Paladino, A. (2007) Investigating the Drivers of Innovation and New Product Success: A Comparison of Strategic Orientations. Journal of Product Innovation Management, 24, 534-553. https://doi.org/10.1111/j.1540-5885.2007.00270.x 
[48] Atuahene-Gima, K., Slater, S.F. and Olson, E.M. (2005) The Contingent Value of Responsive and Proactive Market Orientations for New Product Program Performance. Journal of Product Innovation Management, 22, 464-482. https://doi.org/10.1111/j.1540-5885.2005.00144.x

[49] Han, J.K., Kim, N. and Srivastava, R.K. (1998) Market Orientation and Organizational Performance: Is Innovation a Missing Link? The Journal of Marketing, 64, 30-45. https://doi.org/10.1177/002224299806200403

[50] Langerak, F., Hultink, E.J. and Robben, H.S. (2004) The Role of Predevelopment Activities in the Relationship between Market Orientation and Performance. $R \& D$ Management, 34, 295-309. https://doi.org/10.1111/j.1467-9310.2004.00340.x

[51] Hammond, K.I., Webster, R.L. and Harmon, H.A. (2006) Market Orientation, Top Management Emphasis and Performance within University Schools of Business: Implications for Universities. Journal of Marketing Theory and Practice, 14, 69-85. https://doi.org/10.2753/MTP1069-6679140105

[52] Zahra, S.A. (2008) Being Entrepreneurial and Market Driven: Implications for Company Performance. Journal of Strategy and Management, 1, 125-142. https://doi.org/10.1108/17554250810926339

[53] Voss, G.B. and Voss, Z.G. (2000) Strategic Orientation and Firm Performance in an Artistic Environment. Journal of Marketing, 64, 67-83. https://doi.org/10.1509/jmkg.64.1.67.17993

[54] Yang, Y., Wang, Q., Zhu, H. and Wu, G. (2012) What Are the Effective Strategic Orientations for New Product Success under Different Environments? An Empirical Study of Chinese Businesses. Journal of Product Innovation Management, 29, 166 179. https://doi.org/10.1111/j.1540-5885.2011.00900.x

[55] Park, Y. and Kim, S. (2005) Linkage between Knowledge Management and R \& D Management. Journal of Knowledge Management, 9, 34-44. https://doi.org/10.1108/13673270510610314

[56] Olavarrieta, S. and Friedmann, R. (2008) Market Orientation, Knowledge-Related Resources and Firm Performance. Journal of Business Research, 61, 623-630. https://doi.org/10.1016/j.jbusres.2007.06.037

[57] Ferraresi, A.A., Quandt, C.O., dos Santos, S.A. and Frega, J.R. (2012) Knowledge Management and Strategic Orientation: Leveraging Innovativeness and Performance. Journal of Knowledge Management, 16, 688-701. https://doi.org/10.1108/13673271211262754

[58] Mu, J., Thomas, E., Peng, G. and Di Benedetto, A. (2017) Strategic Orientation and New Product Development Performance: The Role of Networking Capability and Networking Ability. Industrial Marketing Management, 64, 187-201. https://doi.org/10.1016/j.indmarman.2016.09.007

[59] Zare, H. and Mirjalili, M. (2013) Pathology of Invention Process Commercialization: An Analysis in Three Areas of the Inventor, Environment and Invention. Quarterly of Entrepreneurship Development, 6, 37-55.

[60] Migonouri, M. and Ahmadi, B. (2012) Identifying Effective Factors on Selection of Commercialization Strategies for Academic Research in the Field of Petrochemical Industry. Quarterly Journal of Entrepreneurship Development, 5, 27-46.

[61] Slater, S.F. and Narver, J.C. (1998) Research Notes and Communications Customer-Led and Market-Oriented: Let's Not Confuse the Two. Strategic Management Journal, 19, 1001-1006. https://doi.org/10.1002/(SICI)1097-0266(199810)19:10<1001::AID-SMJ996>3.0.CO;2-4

[62] Chandy, R.K. and Tellis, G.J. (2000) The Incumbent's Curse? Incumbency, Size and 
Radical Product Innovation. Journal of Marketing, 64, 1-17.

https://doi.org/10.1509/jmkg.64.3.1.18033

[63] Kleinschmidt, E.J., De Brentani, U. and Salomo, S. (2007) Performance of Global New Product Development Programs: A Resource-Based View. Journal of Product Innovation Management, 24, 419-441.

https://doi.org/10.1111/j.1540-5885.2007.00261.x

[64] Noble, C.H., Sinha, R.K. and Kumar, A. (2002) Market Orientation and Alternative Strategic Orientations: A Longitudinal Assessment of Performance Implications. Journal of Marketing, 66, 25-39. https://doi.org/10.1509/jmkg.66.4.25.18513

[65] Calantone, R.J. and Griffith, D.A. (2007) From the Special Issue Editors: Challenges and Opportunities in the Field of Global Product Launch. Journal of Product Innovation Management, 24, 414-418. https://doi.org/10.1111/j.1540-5885.2007.00260.x

[66] Covin, J.G. and Slevin, D.P. (1989) Strategic Management of Small Firms in Hostile and Benign Environments. Strategic Management Journal, 10, 75-87.

https://doi.org/10.1002/smj.4250100107 